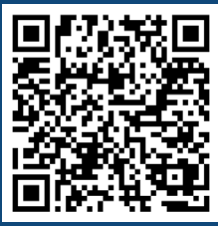

Keywords:

Amazon

CIEL*a*b* system

Wood color

Basic density

Historic:

Received 29/06/2019

Accepted 20/10/2019

Correspondence: wilzacsantos@hotmail.com

Wilza Carla Santos e Sousa ${ }^{\mathrm{la}+}$, Lucas de Jesus Barbosa', Alvaro Augusto Vieira Soares ${ }^{2 \mathrm{a}}$, Selma Lopes Goulart'b, Thiago de Paula Protásio'c

\title{
WOOD COLORIMETRY FOR THE CHARACTERIZATION OF AMAZONIAN TREE SPECIES: A SUBSIDY FOR A MORE EFFICIENT CLASSIFICATION
}

SOUSA, W. C. S.; BARBOSA, L. J.; SOARES, A. A. V.; GOULART, S. L.; PROTÁSIO T. $P$. Wood colorimetry for the characterization of amazonian tree species: a subsidy for a more efficient classification. CERNE, v. 25, n. 4, p.45I-462, 2019.

\section{HIGHLIGHTS}

The colorimetry can be used as a tool in the quality control of wood.

The darker woods with lower luminosity have bigger density.

The color coordinate a* presented the best correlations with the basic density.

The sawing direction can affect wood color.

\section{ABSTRACT}

The wood of different species may present macroscopic similarities, which hinders a reliable differentiation between the specie. This can be a problem, especially in the tropics, given the high species diversity in this region. To overcome this problem of wood identification, colorimetric criteria can be applied, aiming at a better and more objective classification, as opposed to the traditional anatomic criteria. Therefore, the aim of this research was to analyze the variability of the wood color considering the cutting planes (tangential and radial) and to determine its correlation with the wood basic density of ten Amazonian tree species. The following species were studied: Apuleia leiocarpa (amarelão), Hymenolobium modestum (angelim-pedra), Anadenanthera columbrina (angico), Dipteryx odorata (cumaru), Pouteria pachycarpa (goiabão), Mezilaurus itauba (itaubá), Hymenaea courbaril (jatobá), Simarouba amara (marupá), Astronium leicontei (muiracatiara) and, Bowdichia nitida (sucupira). The CIEL*a*b* system was used to determine the colorimetric parameters $\left(\mathrm{L}^{*}, \mathrm{a}^{*}, \mathrm{~b}^{*}, \mathrm{C}^{*}\right.$, and $\left.\mathrm{h}^{*}\right)$, which were obtained through a portable colorimeter. The species were classified in six color specific groups: light yellow, olive brown, yellowish olive, olive light, grayish white and reddish brown. We observed statistical effect of the cut planes only for luminosity, with higher mean for radial face. The correlation analyses between color and basic density showed that the denser woods are darker and have more red pigment $\left(\mathrm{a}^{*}\right)$. There is negative correlation between luminosity $\left(\mathrm{L}^{*}\right)$ and wood basic density $(-0.78)$. The colorimetric parameter $\mathrm{a}^{*}$ presented positive correlation with the basic density $(r=0.80)$.

'Federal Rural University of the Amazon-UFRA, Campus Parauapebas, Parauapebas, Pará, Brazil - ORCID: 00000002-6589-|67| $\left.\right|^{\mathrm{a}}, 0000-0002-1324-\left.493\right|^{\mathrm{b}}, 0000-0002-5560-8350^{c}$ 


\section{INTRODUCTION}

The Amazon region is considered one of the largest reserves of tropical wood in the world, due to its extent, variability and due to the economic and ecological importance of its species. Among the Amazonian natural resources, in the context of sustainable forest management, wood is the one that has the highest economic profitability (ANDRADE et al., 20I9; FORTINI, 20I9).

As it is a heterogeneous biological material, it is possible to find woods of different densities, colors and designs resulting from the combination of xylem anatomical and chemical structures. This combination, during the development of the plant, will result in a great variability of colors in the formed wood. Although some tree species have contrastingly marked wood, various species may present macroscopic similarities that hinder a reliable differentiation between (OLIVEIRA et al., 2015). This is especially relevant in the tropics given the high diversity of tree species. Silva et al. (2017) observed that Amazonian woods presented a wide spectrum of variation of the basic colorimetric parameters (i.e. luminosity range of 40.42 to 83.60 ). Accurate wood identification is indispensable not only for market purposes, but also for the conservation of wood species (VIEIRA et al., 20I9). For example, wood from protected trees species may be traded as a non-protected one with very similar characteristics.

Generally, the technological characterization of wood is based on anatomical studies, in addition to the physical, chemical, and mechanical properties. There are also other parameters of no lesser importance, such as color, which aid the better characterization and use of a particular tree species (SILVA et al., 20I5; VIEIRA et al., 2019). However, the assignment of a specific color exclusively by the visual analysis of an object may be highly subjective, for instance, because of differences intrinsic to the observer perception and to the influence of the light source (BONFATTI JÚNIOR; LENGOWSKI, 2018). It is a very important feature for the identification, classification, and indication of wood uses, especially when associated with texture and design aspects in end uses of higher economic value (BARROS et al., 20l4; VIEIRA et al., 2019).

It is known that the homogeneity of color in a batch of wood influences directly the quality of most products resulting from its processing (MARTINS et al., 20I5). Hence, aiming at the most adequate and profitable final use, color determination stands out as a fundamental factor for the characterization of wood quality, which directly influences the visual aspect and, consequently, its commercialization (MOYA; MARIN, 20II).

In order to circumvent the subjective aspect in the color characterization process, quantitative methods were developed that use numerical variables for the interactions provoked by light on a given surface (BONFATTI JÚNIOR; LENGOWSKI, 20I8; MAIA et al., 20I8; SILVA et al., 20I7; SILVA et al., 2019). Thus, the distinction of wood can be made either by anatomical methods or by non-destructive methods such as colorimetry. Quantitative colorimetry is an objective and effective methodology for measuring the color of wood. Among the systems used for color measurement, CIEL*a*b* is the most used, which is determined through the colorimetric parameters: luminosity $\left(\mathrm{L}^{*}\right)$, color coordinate of the green-red axis ( $\left.\mathrm{a}^{*}\right)$, color coordinate of the blue-yellow axis $\left(b^{*}\right)$, color saturation $\left(C^{*}\right)$, and hue angle (h*) (CAMARGOS; GONÇALEZ, 200I). The incorporation of colorimetric analyses is of fundamental importance to the technological characterization of wood and, consequently, to wood identification and quality control in the industry. This is because color uniformity directly influences the quality of the products resulting from its processing.

The colorimetric properties of tropical timber are desired for furniture manufacturing (ZANUNCIO et al., 2014) and studies have reported the relationship of color variations with the physical and mechanical properties of wood, especially density (MOYA; BERROCAL, 2009; GARCIA et al., 20I4; SILVA et al. 20I7; GRIEBELER et al., 20I8). The relationship between wood density and chromatic variables enables a fast and reliable classification, fostering a correct industrialization and environmentally appropriate use of tropical timber (ALMEIDA et al., 2017). In addition, wood colorimetry may assist in the process of selection and study of new species, especially those with sufficient stock or faster recovery after forest management (AVILA et al., 2017; REIS et al., 2019). By understanding the correlations between chromatic variables and wood density, researchers and technicians will be able to: i) classify and group similar woods using colorimetry as a parameter for quality control; ii) define patterns of wood color variations in different anatomical planes and, iii) establish strategies for the valorization and better aesthetic utilization of the secondary xylem in the forest products industry.

In this context, the aim of this study was to assess the color variability of the wood of ten Amazonian tree species, in different cutting planes (tangential and radial) and to evaluate whether there is a correlation with basic density. 
The investigated hypotheses were: i) the luminosity and the coordinate of the green-red axis $\left(a^{*}\right)$ are the colorimetric characteristics most correlated with the density of the tropical woods; ii) for commercial purposes, there is no statistically significant distinction of the chromatic variables in the different anatomical cutting planes; and iii) colorimetry can be used for rapid classification and inferences about the quality of tropical woods.

\section{MATERIALS AND METHODS}

\section{Preparation of material and determination of basic} density

To carry out this study, woods from ten Amazonian species were obtained from different logging establishments in the municipality of Parauapebas, state of Pará, northern Brazil. The choices of those establishments and woods were based on their importance and representativeness in the various branches of the logging industry of the southeast region of state of Pará, north Brazil (Table I).

TABLE I Tree species selected for this study.

\begin{tabular}{ccc}
\hline Specie & $\begin{array}{c}\text { Common } \\
\text { name }\end{array}$ & Family \\
\hline Apuleia leiocarpa (Vogel) J. F. Macbr & amarelão & Fabaceae \\
Hymenolobium modestum Ducke & angelim-pedra & Fabaceae \\
Anadenanthera columbrina (Vell.) Brenan & angico & Fabaceae \\
Dipteryx odorata (Aubl.) Willd. & cumaru & Fabaceae \\
Pouteria pachycarpa Pires & goiabão & Sapotaceae \\
Mezilaurus itauba (Meissn.) Taub. & itaúba & Lauraceae \\
Hymenaea courbaril L. & jatobá & Fabaceae \\
Simarouba amara Aubl. & marupá & Simaroubaceae \\
Astronium leicontei Ducke & muiracatiara & Anacardiaceae \\
Bowdichia nitida Spruce ex Benth. & sucupira & Fabaceae \\
\hline
\end{tabular}

Boards taken from adult trees were randomly selected, each of which presented the following dimensions: $6 \mathrm{~cm}$ thick, $1.50 \mathrm{~m}$ long and width varying with according to tree diameter. Subsequently, for each species, six samples were produced from the core and free of any defects, totaling 60 samples with nominal dimensions of $2.5 \mathrm{~cm} \times 2.5 \mathrm{~cm} \times 10 \mathrm{~cm}$ (width, thickness, and length, respectively). They were perfectly oriented in the longitudinal, tangential, and radial planes.

In order to avoid the influence of any external effect on the coloring of the wood and to give a uniform surface, guaranteeing more precise results, the surfaces of the samples were sanded with sanding sequence of particle sizes of 120 and 220 , and kept in a temperature controlled room until $12 \%$ moisture was reached.

Wood basic density $\left(\rho_{\mathrm{b}}\right)$ was determined according to the procedures in NBR 7190 (ABNT, 1997), described as the ratio between dry mass and saturated volume. The dry mass was obtained with a digital scale with an accuracy of $0.01 \mathrm{~g}$, after oven drying at $103 \pm 2{ }^{\circ} \mathrm{C}$. Volume was determined by the measurement of the dimensions in the longitudinal, radial, and tangential directions with a digital caliper, after sample saturation.

\section{Determination of color by the CIEL*a*b* system}

The methodology used to determine the colorimetric parameters was the CIEL*a*b* system according to the International Commission of L'Eclairage (CIE) and consists of three coordinates (Figure I). These coordinates include: luminosity or clarity $\left(\mathrm{L}^{*}\right)$ on the black and white axis, which varies from 0 to 100; matrix of the green-red ( $\left.a^{*}\right)$ and blue-yellow (b*) axis, both ranging from -60 to +60 (BARROS et al., 20I4; GARCIA et al., 2014). For the specification of the colors of each species, the color table described by Camargos and Gonçalez (200I) was used.

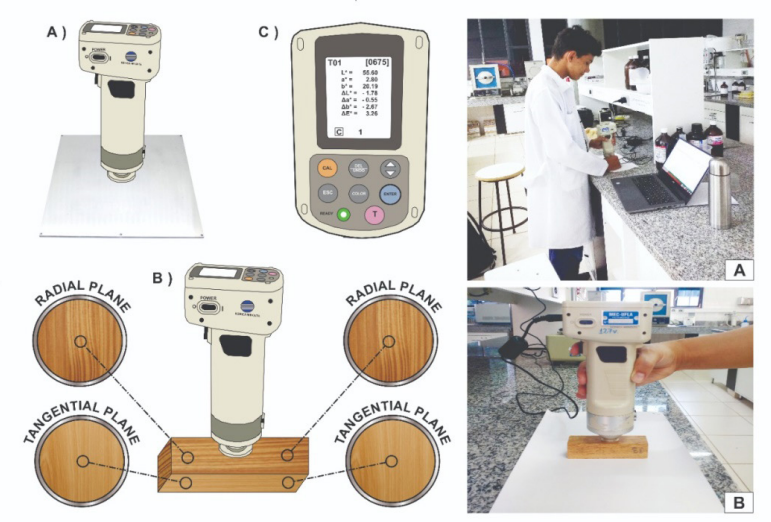

FIGURE I Mensuration of the wood colorimetric parameters. Where: A) Device calibration; B) Measurements on the sample surface in the radial and tangential planes and, C) Storage of colorimetric variables.

Before the analysis, the calibration of the colorimeter was carried out using two references provided by the equipment, one with $L^{*}=100$ (total white) and one with $L^{*}=0$ (total black). Subsequently, the measurements were performed by direct contact of the sample surface with the vision area of the device, using a Konica Minolta portable colorimeter (model CR400) with $8 \mathrm{~mm}$ sensor opening. For that, the instrument was configured to use a light source (illuminant) D65, composed of a xenon lamp that simulates daytime solar radiation, an observation angle of $10^{\circ}$ at room temperature, and illumination area of $\mathrm{II} \mathrm{mm}$ in diameter.

The colorimetric characterization of the wood was carried out in triplicate. There were four measurements at equidistant points, such as two measurements in the radial plane (L*radial, a*radial, and $b^{*}$ radial) and two measurements in the tangential plane ( $L *$ tangential, $\mathrm{a} *$ tangential, and $\mathrm{b} *$ tangential). 
In this sense, the following colorimetric parameters were obtained: luminosity $\left(L^{*}\right)$, color coordinate greenred $\left(a^{*}\right)$, color coordinate blue-yellow $\left(b^{*}\right)$, color saturation $\left(\mathrm{C}^{*}\right)$, and hue angle $\left(\mathrm{h}^{*}\right)$. For calculation of the saturation parameters of the color ( $\left.\mathrm{C}^{*}\right)$ and the hue angle ( $\left.\mathrm{h}^{*}\right)$, equations I and 2 were used, respectively, where: C* - Color saturation, $\mathrm{a}^{*}$ - Color coordinate in the greenred axis, and $b^{*}$ - Color coordinate in the blue-yellow axis, equation 2, Where: $h^{*}$ - Hue angle, $a^{*}$ - Color coordinate in the green-red axis, and $b^{*}$ - Color coordinate in the blue-yellow axis.

$$
\begin{aligned}
& \mathrm{C}^{*}=\sqrt{(a *)^{2}+(b *)^{2}} \\
& \mathrm{~h}^{*}=\tan ^{-1}\left(\frac{\mathrm{b} *}{\mathrm{a} *}\right)
\end{aligned}
$$

\section{Statistical analysis of data}

The data collected by the colorimeter were exported to the SpectraMagic ${ }^{\mathrm{TM}} \mathrm{NX}$ software (CMSI00w), version 1.9 (Konica Minolta, 2007). The statistical analyses of data were realized in software $R$ version 3.4.3 (R CORE TEAM, 2019). The dependent variables studied were: (i) colorimetric parameters luminosity or clarity $\left(\mathrm{L}^{*}\right)$, color coordinate green-red (a*), color coordinate blue-yellow (b*), color saturation $\left(\mathrm{C}^{*}\right)$, and hue angle (h*); and (ii) basic density of the wood of ten Amazonian tree species.

The data obtained were submitted to the homogeneity test of variances (Bartlett's test, BrownForsyth's test and Levene's test, at 5\% probability); the normality of residues (ShapiroWilk's test and Kolmogorov-Smirnov's test, at $5 \%$ probability), and the Durbin-Watson's test for autocorrelation of disturbances. For the parameters evaluated in the wood ( $\mathrm{L}^{*}, \mathrm{a}^{*}, \mathrm{~b}^{*}, \mathrm{C}^{*}$, $\mathrm{h}^{*}$ and wood density), the assumptions of homogeneity of variance, normal distribution and absence of autocorrelation of the disturbances required for the use of parametric statistics ( $F$ test) were checked. Then, the colorimetric parameters of the wood were submitted to ANOVA, considering the completely randomized design in double factorial scheme (species $\mathrm{x}$ cutting planes) with three repetitions. We considered ten levels for the species factor and two levels for the cutting planes factor. The data of the basic wood density were submitted to ANOVA, considering the completely randomized design with ten species and three repetitions. The factors studied are qualitative and, therefore, for the multiple comparisons of means, the Scott-Knott test was used at $5 \%$ significance level (SCOTT; KNOTT, 1974).

Correlations between the colorimetric parameters $\left(\mathrm{L}^{*}, \mathrm{a}^{*}, \mathrm{~b}^{*}, \mathrm{C}^{*}\right.$ and $\left.\mathrm{h}^{*}\right)$ and the wood basic density were determined by the Pearson correlation method at $5 \%$ significance level by $t$ test. In order to test for the ability to predict basic density based in the colorimetric parameters, the following linear equations were fit using the ordinary least squares method: $\rho_{\mathrm{b}}=\beta_{0}$ $+\beta_{1}{ }^{\star} L+\beta_{2}{ }^{\star} L^{2}+\varepsilon$, and $\rho_{b}=\beta_{0}+\beta_{1}{ }^{\star} a+\beta_{2}{ }^{*} a^{2}+\varepsilon$; where $\rho_{b}$ $=$ wood basic density $\left(\mathrm{g} \mathrm{cm}^{-3}\right) ; \mathrm{L}=$ luminosity; $\mathrm{a}=$ color coordinate in the green-red axis; $\beta_{0}, \beta_{1}$ and $\beta_{2}$ regression coefficients; $\varepsilon=$ random error. The luminosity ( $\left.L^{*}\right)$ and color coordinate in the green-red axis (a*) were used in the modeling, because presented the highest correlations with wood basic density.

\section{RESULTS AND DISCUSSION}

The results obtained for the wood basic density of the ten species studied are presented in Figure 2.

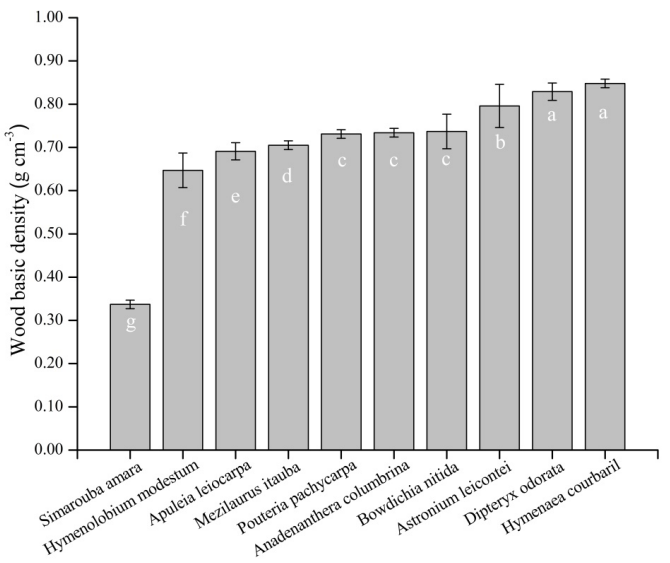

FIGURE 2 Wood basic density of ten Amazonian tree species. Columns followed by the same letter do not show difference by the Scott-Knott test $(p \leq 0.05)$. The bars represent standard deviation.

The statistical analyses indicated significant differences between the wood basic density of the ten species and this result may directly influence the uses and colorimetry of wood of the Amazonian tree species. The lowest and the highest values of basic densities were found for marupá (Simarouba amara) and jatobá

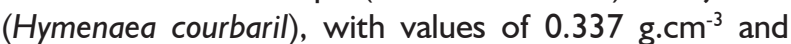
$0.848{\mathrm{~g} . \mathrm{cm}^{-3}}^{-3}$, respectively. Recently, Andrade et al. (2019) demonstrated that wood density is closely related to tree age and growth, with low-density Amazonian species $\left(<0.600 \mathrm{~g} \mathrm{~cm}^{-3}\right)$ showing rapid growth and high-density tree species characterized by slow growth. The wood of $H$. courbaril has a high density range of $0.76-0.96 \mathrm{~g}$ $\mathrm{cm}^{-3}$ (ANDRADE et al., 2019) and is widely distributed in Brazil, occurring in dryland forests in the Amazon (LOCOSSELLI et al., 20I7) and heavily marketed because of the high values and low variability of mechanical properties that enable structural use (LAHR et al., 20I6). 
The basic density variations described in this study are in accordance with the values found in the literature for most tropical timber species (ARAÚJO, 2007; IPT, 2013; PEREIRA, 2013; REIS et al., 2019). However, there were some exceptions, probably due to site differences, such as variations in soil fertility, tree age, climatic factors and growth of the species. These environmental variations can affect anatomical and chemical constituents, which can result in considerable variation between species and between individual of the same species. According to Sette Junior et al. (20I2), the variations of density are related to the differences in the anatomical structure of the wood and the amount of extractive substances present per unit of volume, but there is no consensus on how this variation occurs.

Of the ten sampled species, only the marupá species (Simarouba amara) was classified as low density wood $\left(<0.500 \mathrm{~g} \mathrm{~cm}^{-3}\right)$. The wood of the species Hymenolobium modestum, Apuleia leiocarpa, Mezilaurus itauba, Pouteria pachycarpa and Anadenanthera columbrina presented basic density between 0.500-0.750 $\mathrm{g} \mathrm{cm}^{-3}$ and, therefore, were classified as moderate density woods. The species Astronium leicontei, Dipteryx odorata, Hymenaea courbaril and Bowdichia nitida presented density higher than $0.750 \mathrm{~g} \cdot \mathrm{cm}^{-3}$ and were classified as heavy and high density woods (CSANÁDY et al., 2015). It was observed that $50 \%$ of the woods studied were classified as medium density and only $40 \%$ high density. Nogueira et al. (2005) evaluated the basic density of 186 Amazonian tree species and found that $73 \%$ of the species were classified as moderate-weight wood and only $23 \%$ as heavy woods. These results demonstrate that, in the Amazon region, there is a predominance of tree species with medium wood density, which is relevant for growth studies and for the definition of cutting cycles adopted in sustainable forest management (ANDRADE et al., 2019) and for the replacement of overexploited species with others with similar wood properties and sufficient growth stock (REIS et al., 2019).

Knowing the wood density, one can make inferences regarding the beneficiation and specific cutting force (MELO et al., 20I6), the physical (EVANGELISTA; COSTA, 2017) and mechanical properties (STANGERLIN et al., 2017) and consequently, assign the most proper end use of the wood, i.e. construction, floors production or furniture. Due to the low density of the wood, the species Simarouba amara is recommended, for example, for purposes that require less mechanical resistance or situations where the wood is subjected to less external stress, such as lining, packaging and laminate. The species with moderate density can be used for the production of floors, furniture and construction (frames, doors, slats, baseboards and ceilings) (IPT, 20I3). Due to the high basic density, the woods of the species Astronium leicontei, Bowdichia nitida, Dipteryx odorata and Hymenaea courbaril can be used for furniture making or for structural use, that is, to build houses in the wood frame system.

Tables 2 and 3 present the average values of the colorimetric parameters ( $L^{*}, a^{*}, b^{*}, C^{*}$, and $\left.h^{*}\right)$ of the wood of the ten species for the tangential and radial faces. There was no statistically significant effect of the interaction between factors species $x$ anatomical cutting plane for the variables: luminosity $\left(L^{*}\right)$, color coordinates ( $\mathrm{a}^{*}$ and $\mathrm{b} *$ ), and color saturation ( $\left.\mathrm{C}^{*}\right)$. For these variables we proceeded to the analysis of the factors species and anatomical plane of cut individually. For the hue angle $\left(h^{*}\right)$ a significant effect of the species $x$ anatomical plane interaction was observed. Significant interaction effect indicates dependence on the studied factors and, therefore, it was necessary to unfold the effect of cutting plane factor inside of each level of species and the effect of the species factor inside of each level of cutting planes.

The species evaluated in this study presented a broad spectrum of variation for the basic colorimetric parameters: luminosity $\left(\mathrm{L}^{*}\right)$ between 49.96 and 83.62; color coordinate $\mathrm{a}^{*}$ between -2.09 and 10.28; color coordinate $b^{*}$ between 20.19 and 31.54 ; color saturation (C*) between 20.9I and 34.25; and hue angle ( $\left.h^{*}\right)$ between -69.42 and 85.70. According to Camargos and Gonçalez (200I), species with light values ( $\left.L^{*}\right)$ above 56 are considered light woods, and species with a light value ( $\left.L^{*}\right)$ less than or equal to 56 are considered dark woods. Thus, considering the average value observed for the specie (Table 3), the color of the wood of the species amarelão (Apuleia leiocarpa), angelim-pedra (Hymenolobium modestum), angico (Anadenanthera columbrina), goiabão (Pouteria pachycarpa), itaúba (Mezilaurus Itauba), jatobá (Hymenaea courbaril), marupá (Simarouba amara), and muiracatiara (Astronium leicontei) were classified as light, while the wood of the species cumaru (Dipteryx odorata) and sucupira (Bowdichia nitida) were classified as dark. According to Silva et al. (20I7), woods with low $L^{*}$ values tend to have dark surfaces.

For the radial section, the mean values of the colorimetric parameters were $\left(L^{*}=65.84 ; a^{*}=4.65\right.$; $b^{*}=27.85 ; C^{*}=28.46 ;$ and $\left.h^{*}=62.50\right)$, and for the tangential section, the mean values were $\left(L^{*}=63.36\right.$; $\mathrm{a}^{*}=5.0 \mathrm{I} ; \mathrm{b}^{*}=27.12 ; \mathrm{C}^{*}=27.79 ;$ and $\left.\mathrm{h}^{*}=6 \mathrm{I} .6 \mathrm{I}\right)($ Table 2). The average values of all the parameters were higher in the radial face in relation to the tangential face, except for the $a^{*}$ coordinate for which higher values were found 
TABLE 2 Mean values obtained for the color variables in the CIEL*a*b* system for the radial (Rd) and tangential (Tg) faces of the species under study.

\begin{tabular}{|c|c|c|c|c|c|c|}
\hline $\begin{array}{c}\text { Species } \\
\text { A. leiocarpa }\end{array}$ & $\begin{array}{l}\text { Face } \\
\text { Rd }\end{array}$ & $\begin{array}{c}L^{*} \\
68.18(1.66)\end{array}$ & $\begin{array}{c}\mathrm{a}^{*} \\
3.05(0.13)\end{array}$ & $\begin{array}{c}b^{*} \\
31.63(2.15)\end{array}$ & $\begin{array}{c}\text { C* }^{*} \\
31.78(2.14)\end{array}$ & $\begin{array}{c}\mathrm{h}^{*} \\
84.43(0.55) \mathrm{bA}\end{array}$ \\
\hline (Amarelão) & $\mathrm{Tg}$ & $66.16(1.22)$ & $4.11(0.13)$ & $31.45(2.25)$ & $31.71(2.22)$ & $82.59(0.29) b B$ \\
\hline H. modestum & $\mathrm{Rd}$ & $67.87(1.75)$ & $6.24(0.73)$ & $29.00(0.44)$ & $29.67(0.27)$ & $77.87(1.58) \subset A$ \\
\hline (Angelim pedra) & $\mathrm{Tg}$ & $68.14(0.68)$ & $6.03(0.28)$ & $30.29(0.57)$ & $30.88(0.60)$ & $78.75(0.34) \mathrm{d} A$ \\
\hline A. columbrina & Rd & $73.77(1.23)$ & $3.60(0.57)$ & $32.00(0.58)$ & $32.20(0.52)$ & $83.56(\mathrm{I} .1 \mathrm{I}) \mathrm{b} A$ \\
\hline (Angico) & $\mathrm{Tg}$ & $70.12(1.91)$ & $5.06(0.83)$ & $30.36(0.55)$ & $30.79(0.60)$ & $80.52(1.49)$ c B \\
\hline D. odorata & Rd & $56.08(0.66)$ & $6.83(0.50)$ & $24.34(0.87)$ & $25.28(0.94)$ & $74.32(0.73) \mathrm{d} A$ \\
\hline (Cumaru) & $\mathrm{Tg}$ & $50.74(0.79)$ & $7.96(0.38)$ & $23.38(0.98)$ & 24.7I(I.04) & $71.15(0.25) \mathrm{fB}$ \\
\hline P. pachycarpa & Rd & $73.57(1.05)$ & $2.4 \mathrm{I}(0.69)$ & $31.64(2.59)$ & $31.73(2.63)$ & $85.71(0.93)$ a A \\
\hline (Goiabão) & $\mathrm{Tg}$ & $68.59(1.08)$ & $3.38(0.86)$ & $30.50(1.61)$ & $30.69(1.69)$ & $83.7 \mathrm{I}(\mathrm{I} .28) \mathrm{b} B$ \\
\hline M. itauba & Rd & $61.47(3.23)$ & $2.18(0.25)$ & $27.76(3.01)$ & $27.84(2.98)$ & $85.4 I(I .13)$ a A \\
\hline (Itaúba) & $\mathrm{Tg}$ & $61.30(0.74)$ & $1.89(0.06)$ & $26.64(1.68)$ & $26.71(1.68)$ & $85.93(0.17)$ a A \\
\hline H. courbaril & $\mathrm{Rd}$ & 63.38(1.89) & $8.11(1.38)$ & $29.05(1.93)$ & $30.17(2.21)$ & $74.47(\mathrm{I} .64) \mathrm{d} A$ \\
\hline (Jatobá) & $\mathrm{Tg}$ & $62.46(2.77)$ & $8.55(0.31)$ & $29.00(1.89)$ & $30.24(I .89)$ & $73.55(0.46)$ e $A$ \\
\hline S. amara & Rd & $84.79(0.46)$ & $-2.07(0.06)$ & $24.32(0.46)$ & $24.41(0.45)$ & $-85.13(0.24) f A$ \\
\hline (Marupá) & $\mathrm{Tg}$ & $82.46(2.08)$ & $-2.11(0.25)$ & $23.36(0.92)$ & $23.46(0.89)$ & $-84.76(0.76)$ g A \\
\hline A. leicontei & Rd & $57.81(1.07)$ & $10.55(1.36)$ & $27.93(1.79)$ & $29.87(2.09)$ & $69.32(1.63)$ e A \\
\hline (Muiracatiara) & $\mathrm{Tg}$ & $55.25(6.04)$ & $10.00(1.58)$ & $26.7 I(4.08)$ & $28.53(4.37)$ & $69.50(0.42) \mathrm{fA}$ \\
\hline B. nitida & $\mathrm{Rd}$ & $51.53(0.81)$ & $5.62(0.43)$ & $20.86(0.32)$ & $21.60(0.20)$ & $74.91(1.30) \mathrm{d} A$ \\
\hline (Sucupira) & $\mathrm{Tg}$ & $48.39(0.77)$ & $5.20(0.6 \mathrm{I})$ & $19.53(1.16)$ & $20.21(1.26)$ & $75.14(0.94)$ e A \\
\hline Mean & $\begin{array}{l}\mathrm{Rd} \\
\mathrm{Tg}\end{array}$ & $\begin{array}{l}65.84 \\
63.36\end{array}$ & $\begin{array}{l}4.65 \\
5.01\end{array}$ & $\begin{array}{l}27.85 \\
27.12\end{array}$ & $\begin{array}{l}28.46 \\
27.79\end{array}$ & $\begin{array}{l}62.49 \\
61.61\end{array}$ \\
\hline CVe (\%) & - & 3.13 & 14.86 & 6.47 & 6.58 & 1.60 \\
\hline
\end{tabular}

Different uppercase letters indicate significant difference between means within the same species (effect of cutting plane factor inside of each level of species), by the Scott-Knott test at 5\% significance level. Different lowercase letters indicate effect of the species factor inside of each level of cutting planes, by the Scott-Knott test at $5 \%$ significance level. $\mathrm{CVe}=$ experimental coefficient of variation. Parenthetical numbers are the associated standard deviations

for the tangential face. However, anatomical cutting plane had an effect only over luminosity, with the largest mean for the radial face. Melo et al. (2019) researching the groups of commercial tropical timber using the colorimetry observed that all analyzed colorimetric parameters did not show a statistical difference between the assessed planes - radial and tangential.

TABLE 3 Mean values obtained for the color variables in the CIEL*a*b* system for the radial (Rd) and tangential ( $\mathrm{Tg})$ faces of the species under study.

\begin{tabular}{|c|c|c|c|c|c|}
\hline Species & $L^{*}$ & $\mathrm{a}^{*}$ & $\mathrm{~b}^{*}$ & C* & $\mathrm{h}^{*}$ \\
\hline $\begin{array}{l}\text { A. leiocarpa } \\
\text { (Amarelão) }\end{array}$ & $67.17(1.71) C$ & 3.58(0.59) E & $31.54(1.96) \mathrm{A}$ & $31.75(1.95) \mathrm{A}$ & $83.5 \mathrm{I}(\mathrm{I} .08)$ \\
\hline $\begin{array}{c}\text { H. modestum } \\
\text { (Angelim pedra) }\end{array}$ & $68.00(1.20) \mathrm{C}$ & $6.13(0.5 I) D$ & $29.65(0.84) \mathrm{A}$ & $34.25(0.78) \mathrm{A}$ & $73.66(1.13)$ \\
\hline $\begin{array}{l}\text { A. columbrina } \\
\text { (Angico) }\end{array}$ & $71.95(2.47) \mathrm{B}$ & $4.33(1.02) \mathrm{E}$ & $31.18(1.03) \mathrm{A}$ & $31.50(0.93) \mathrm{A}$ & $82.06(2.04)$ \\
\hline $\begin{array}{l}\text { D. odorata } \\
\text { (Cumaru) }\end{array}$ & $53.4 \mathrm{I}(3.00) \mathrm{F}$ & $7.40(0.74) \mathrm{C}$ & $23.86(0.98) C$ & $25.00(0.94) \mathrm{C}$ & $72.76(1.80)$ \\
\hline $\begin{array}{l}\text { P. pachycarpa } \\
\text { (Goiabão) }\end{array}$ & 7I.08(2.89) B & $2.89(0.88) F$ & $31.07(2.03) \mathrm{A}$ & $31.21(2.06) \mathrm{A}$ & $84.72(1.48)$ \\
\hline $\begin{array}{l}\text { M. itauba } \\
\text { (Itaúba) }\end{array}$ & $61.39(2.10) \mathrm{D}$ & $2.03(0.23) \mathrm{G}$ & $27.20(2.26) \mathrm{B}$ & $27.28(2.25) \mathrm{B}$ & $85.70(0.78)$ \\
\hline $\begin{array}{l}\text { H. courbaril } \\
\text { (Jatobá) }\end{array}$ & $62.92(2.18) \mathrm{D}$ & $8.33(0.92) B$ & $29.02(I .7 I) B$ & $30.2 \mathrm{I}(\mathrm{I} .84) \mathrm{A}$ & $74.01(1.19)$ \\
\hline $\begin{array}{l}\text { S. amara } \\
\text { (Marupá) }\end{array}$ & $83.62(1.85) \mathrm{A}$ & $-2.09(0.16) \mathrm{H}$ & $23.84(0.83) \mathrm{C}$ & $23.94(0.82) \mathrm{C}$ & $-84.98(0.54)$ \\
\hline $\begin{array}{c}\text { A. leicontei } \\
\text { (Muiracatiara) }\end{array}$ & $56.53(4.12) \mathrm{E}$ & $10.28(1.35) \mathrm{A}$ & $27.32(2.89) B$ & $29.20(3.15) B$ & $69.42(1.07)$ \\
\hline $\begin{array}{c}\text { Bodichia nitida } \\
\text { (Sucupira) }\end{array}$ & $49.96(1.86) \mathrm{G}$ & $5.4 I(0.52) D$ & $20.19(1.05) \mathrm{D}$ & $20.9 I(I . I I) D$ & $75.02(1.02)$ \\
\hline
\end{tabular}

Different uppercase letters indicate significant difference between means by the Scott-Knott test at $5 \%$ significance level. Parenthetical numbers are the associated standard deviations. radial and tangential faces, it was observed that the radial face is lighter ( $\left.L^{*}\right)$ for nine woods, except for the angelimpedra (Hymenolobium modestum). This can be justified by the significant increase of the color coordinates ( $\mathrm{a}^{*}$ and b*), implying a greater color saturation in this face. The hue angles ( $\mathrm{h}^{*}$ ) help explain the lighter colors of this face, 
bringing them closer to the yellow axis in relation to the tangential face. Burguer and Richter (1991) affirm that the anatomical section radial is more glistening, due to the effect of the horizontal bands of the rays. In addition, microscopic studies have revealed that discolored chemicals in wood are concentrated in ray parenchyma cells, justifying the greater radiance and low-yellowish hue found in the radial plane (MÖTTÖNEN; KÄRKI, 2007; LUOSTARINEN; MÖTTÖNEN, 2009).

This colorimetric difference between the tangential and radial sections, mainly for luminosity, can be attributed to the anatomical characteristics of the wood. According to Silva et. (20I5), there is a greater surface exposure of radial parenchyma due to the existence of rays of larger dimensions, as well as the presence of reserve substances in the radial parenchyma, which could explain the fact that the radial section presents clearer coloration, due to the greater proximity between the radial cells.

Considering the statistical differences observed for the luminosity in the different anatomical cutting planes, it is possible to highlight the importance of the color in the choice of the breakdown system for the Amazonian woods. The significant differences between the observation sections, given by the luminosity parameter, indicate that the sawing direction can affect wood color. It is, therefore, recommended that the cut orientation (tangential or radial) of these wood species should be performed in accordance with the market requirements. In addition, such information may support a pre-classification of wood, allowing for the timber sector to obtain more homogeneous wood for its color, and implying the manufacturing of more uniform products.

If consumers and technicians prefer wood with lighter shades, the logs should be split in the radial plane, as $L^{*}$ values are higher in this plane. For the acquisition of lots of darker wood, the tangential development is the most appropriate, regardless of the species. The difference in brightness on the radial and tangential faces can assist in the separation of wood for subsequent kiln drying, that is, sawn pieces with lower brightness values indicate tangentially oriented planks and could be arranged in specific piles. The Brazilian industry commonly dries different types of sawn pieces on the same conventional drying load and the specialized literature reports that tangential boards tend to have a pronounced plumbing defect, unlike radial boards (BATISTA et al., 20I5).

Most of the species presented positive values for the $\mathrm{a}^{*}$ and $\mathrm{b}^{*}$ coordinates (see Tables 2 e 3), which classifies them in the first quadrant of colors in the CIEL*a*b* system. This is the expected pattern for wood coloration. This result indicates that the studied woods, mainly of the species $A$. leicontei, $D$. odorata and $H$. courbaril, have more reddish coloration. The exception was the Marupá species (Simarouba amara), which presented in the coordinate a* negative value. This result justifies the decrease in color saturation $\left(\mathrm{C}^{*}\right)$ and hue angle $\left(h^{*}\right)$ of $S$. amara wood, colorimetric properties directly related to the behavior of parameters $\mathrm{a}^{*}$ and $\mathrm{b}^{*}$. Thus, this result attributed greyish tones in the coloring of the wood of marupá (Simarouba amara).

Determining the colorimetry of Amazonian woods is of great importance in obtaining uniform lots of sawn wood according to market convenience, which directly influences the quality of most products resulting from its processing (STANGERLIN et al., 2013). Besides that, the groups of species by color is a possibility for marketing in local wood market, where often clients search for products based only in their esthetic appearance (MELO et al., 2019).

According to the classification proposed by Camargos and Gonçalez (200I), considering the colorimetric parameters of the CIEL*a*b* system, the color of the species was classified as follows (Figure 3 ). The color variation of the studied woods is a result of the combination of anatomical and chemical factors (MELO et al., 2019). For example, the yellow tones of wood are primarily governed by the photochemistry of wood, particularly in lignin (SANDOVAL-TORRES et al., 2010). On one hand, the color coordinate in the green-red axis (a*) is commonly associated with the hot water extractives content of wood, that is, the increased extractives content are associated with reddish woods (YAZAKI et al., 1994).

Amarelão (Apuleia leiocarpa), angelim-pedra (Hymenolobium modestum), and angico (Anadenanthera columbrina) as light yellow (Figure 3 ). Both coordinates ( $\mathrm{a}^{*}$ and $\left.b^{*}\right)$ act in the formation of the color of these woods. However, due to the greater influence of the coordinate $b^{*}$, which has greater values than the coordinate $a^{*}$, they fit in the first quadrant of the CIEL*a*b* system and, hence, closer to the yellow axis. The high values of the color coordinates a* and mainly b* result in the high $\mathrm{C}^{*}$ value, which, associated with high $L^{*}$ values, resulted in the marked color of these species. The $h^{*}$ near 80 also shows the influence of the two coordinates on the color formation of these woods. The species amarelão (Apuleia leiocarpa) and angico (Anadenanthera columbrina) were classified in the same group for colorimetric parameters a* e b*, by Scott-Knott test's (Table 3), reinforcing the classification of these species in the same color group.

The species itaúba (Mezilaurus itauba) and muiracatiara (Astronium leicontei) were classified as olive brown. The wood of cumaru (Dipteryx odorata) and 


\begin{tabular}{|c|c|c|}
\hline COLOR CLASSIFIC & ATION & \\
\hline Group 1 - Light yellow & & \\
\hline Apuleia liocarpa (amarelão) & & \\
\hline Hymenolobium modestum (angelim-pedra) & & \\
\hline Anadenanthera columbrina (angico) & 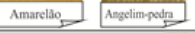 & Angiko \\
\hline Group 2 - Olive brown & & \\
\hline Mezilaurus itauba (itaúba) & & \\
\hline Astronio leicontei (muiracatiara) & thaibus & \\
\hline Group 3 - Yellowish olive & & \\
\hline Dypteryx odorata (cumaru) & & \\
\hline Hymenaea coubaril (jatobá) & Cumanus & 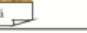 \\
\hline Group 4 - Olive light & & \\
\hline Pouteria pachycarpa (goiabão) & & \\
\hline & & \\
\hline Group 5 - Grayish white & & \\
\hline Simarouba amara (marupá) & & \\
\hline & & \\
\hline Group 6 - Reddish brown & & \\
\hline Bowdichia nitida (sucupira) & & \\
\hline & Souplat of & \\
\hline
\end{tabular}

FIGURE 3 Color classification according to the wood color table proposed by Camargos and Gonçalez (200I).

jatobá (Hymenaea courbaril) were classified as yellowish olive (Figure 3). All the wood samples of these species had a marked influence of the $b^{*}$ coordinate in the formation of their colors. However, according to the literature (CAMARGOS; GONÇALEZ, 200I; GONÇALEZ et al., $200 \mathrm{I})$, the definition of the color of the species belonging to the two groups (olive brown and yellowish olive) is defined by the greater or lesser participation of the coordinate $\mathrm{a}^{*}$. The color saturation $\left(\mathrm{C}^{*}\right)$ and hue angle (h*) were high for all species, confirming the importance of the two coordinates in the color formation of these species (see Table 3).

The species marupá (Simarouba amara) had the color classified as grayish white (Figure 3 ). The coloration of this species also had great influence of the coordinate b*, which presented high values. The species marupá (Simarouba amara) had the color classified as grayish white. The coloration of this species also had great influence of the coordinate $\mathrm{b}^{*}$, which presented high values. The lower hue angle values ( $h *$ ), mean of -84.98 , helped to explain the more whitish colors of the wood of this species (Table 3 ).

The species goiabão (Pouteria pachycarpa) was classified as olive light and sucupira (Bowdichia nitida) as reddish brown (Figure 3 ) and different proportions of the $a^{*}$ and $b^{*}$ coordinates were shown for each of these two species. The $\mathrm{a}^{*}$ coordinate has a pronounced participation in the color formation of the $B$. nitida species. On the other hand, the decrease in the value of $a^{*}$ causes the coordinate $b^{*}$ to act decisively in the final color of the wood of the goiabão, as compared to the sucupira. The hue angle (h*) demonstrated the positioning of the two species along the red and yellow axes, corroborating the definition of the color of these woods.

Since it was observed that even different species have similar colorimetric patterns, it was possible to group the analyzed species into groups of colors with colorimetry. Thus, this technique proved effective to be used as a support tool in species identification, as long as it is used with other characterization techniques. However, such comparisons must be made with caution, since in addition to the diversity of their intrinsic characteristics (chemical and anatomical), the wood may present color alteration due to external effects (STANGERLIN et al., 20I3), such as: local climatic conditions, sampling position and silvicultural treatments (DERKYI et al., 2009; ATAYDE et al., 20I I).

Table 4 shows the correlation values of the colorimetric parameters ( $\mathrm{L}^{*}, \mathrm{a}^{*}, \mathrm{~b}^{*}, \mathrm{C}^{*}$, and $\mathrm{h}^{*}$ ) with the wood basic density for the studied species. No significant correlation was observed between basic density and the parameter $b^{*}$ for the evaluated species. This result can be attributed to the small variations between the mean values of the parameter $b^{*}$ for the studied species woods.

TABLE 4 Pearson correlation coefficient between the means of the colorimetric parameters luminosity $\left(L^{*}\right)$, color coordinate green-red (a*), color coordinate blueyellow ( $\left.b^{*}\right)$, color saturation ( $\left.\mathrm{C}^{*}\right)$, hue angle ( $\mathrm{h}^{*}$ ) and the wood basic density $(\rho b)$ of the Amazonian tree species under study.

\begin{tabular}{cccccc}
\hline & $\mathrm{L}^{*}$ & $\mathrm{a}^{*}$ & $\mathrm{~b}^{*}$ & $\mathrm{C}^{*}$ & $\mathrm{~h}^{*}$ \\
\hline $\mathrm{a}^{*}$ & $-0.69^{*}$ & - & - & - & - \\
$\mathrm{b}^{*}$ & $0.43^{*}$ & $0.08 \mathrm{~ns}$ & - & - & - \\
$\mathrm{C}^{*}$ & $0.34 \mathrm{~ns}$ & $0.22 \mathrm{~ns}$ & $0.99 *$ & - & - \\
$\mathrm{h}^{*}$ & $-0.6 \mathrm{I}^{*}$ & $0.60^{*}$ & $0.37 \mathrm{~ns}$ & $0.40^{*}$ & - \\
$\mathrm{\rho b}$ & $-0.78^{*}$ & $0.80^{*}$ & $0.1 \mathrm{Ins}$ & $0.19 \mathrm{~ns}$ & $0.85^{*}$ \\
\hline
\end{tabular}

The colorimetric parameter that obtained better correlation with the basic density was the hue angle ( $\left.\mathrm{h}^{*}\right)$. Together with the color coordinate $\left(b^{*}\right)$, this confirms the greater proximity to the yellow axis, evidencing the importance of the yellow pigment ( $\left.b^{*}\right)$ in the formation the color of the wood of these species. In addition, the parameter $b^{*}$, was also significantly and positively correlated $(r=0.99)$ with color saturation ( $\left.C^{*}\right)$. According to Pincelli et al. (20I2), chromophore composites associated with lignins and extractives impart a yellowish color to the wood. These results are in agreement with studies carried out by the Forest Products Laboratory (FPL, 20I0), which stated that the denser woods have a higher extractive content and are darker.

We observed which $82 \%$ of the variation in the basic wood basic density of the Amazonian tree species was explained by luminosity and red hue (Figures 4 
and 5). This result is justified by the fact that the basic density is not the main factor influencing the colorimetric variation of wood, but rather, it is the amount of chemical compounds, such as extractives and lignin, that influence this characteristic (YAZAKI et al., 1994; DERKYI et al., 2009; TELES; COSTA, 20I4; MESQUITA et al., 2017). Extractives are the main chromophores components that interfere in these indices of colorimetry analysis (PINCELLI et al., 20I2), especially in red pigmentation (YAZAKI et al., 1994). According to Barreto and Pastore (2009), the extractives of Brazilian tropical tree species are very diverse, both in quantity and chemical nature.

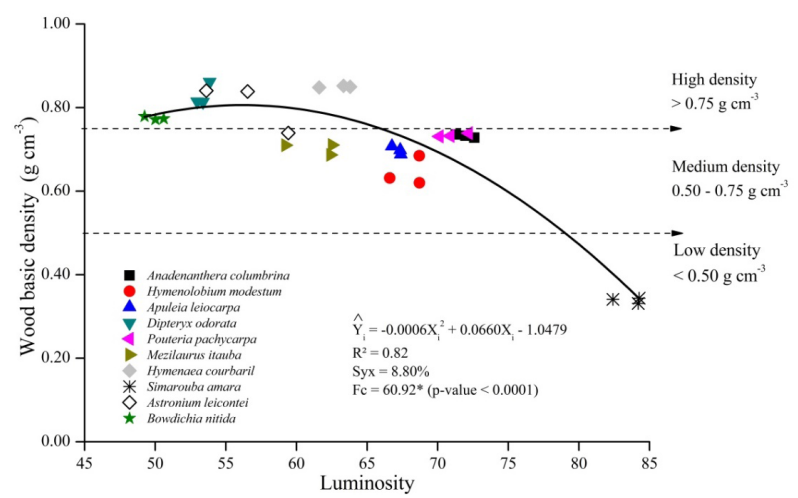

FIGURE 4 Relationship between the basic density and luminosity of the wood of ten Amazonian tree species.

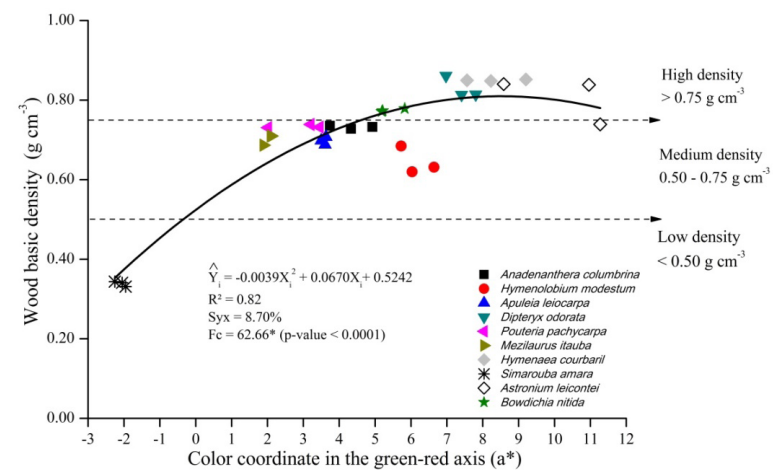

FIGURE 5 Relationship between the basic density and color coordinate in the green-red axis ( $\left.a^{*}\right)$ of the wood of ten Amazonian tree species.

The wood density of Amazonian tree species showed a significant negative correlation with the L*, indicating that the denser woods are darker (lower L*). Hittler et al. (1972) described that, like the color coordinate $a^{*}$, the luminosity $\left(L^{*}\right)$ is also related to the greater or lesser amount of extractives present in the wood. Nishino et al. (2000) also pointed out that the colorimetric parameter $\left(L^{*}\right)$ is directly influenced by the basic density variation, especially for tangentially oriented woods.

The negative correlation between luminosity and basic density has been reported in the literature by Silva et al. (20I5) for Araucaria angustifolia wood ( $r=$
0.82) and, Amorim et al. (2013) for Eucalyptus grandis and Pinus caribea $(r=0.70)$ woods, corroborating the results found in this research for tropical woods. From the regression model adjusted between basic density and luminosity, this colorimetric parameter can be used to make inferences about wood quality and to quickly classify species according to basic density, because the colorimeter is a portable equipment and easy to handle in the courtyards of the timber industries present in the Amazon region. Overall, we observed that woods with luminosity greater than 79 were classified as low density $\left(<0.50 \mathrm{~g} \mathrm{~cm}^{-3}\right)$, medium density $\left(0.50-0.75 \mathrm{~g} \mathrm{~cm}^{-3}\right)$ when luminosity between $66-79$, and high density $(>0.75 \mathrm{~g}$ $\mathrm{cm}^{-3}$ ) when luminosity was lower than 66 . Among the ten species analyzed, only Mezilaurus itauba wood with luminosity $<66$ was classified as medium density. This result may have been influenced by the value obtained for red hue ( $\left.a^{*}\right)$ of this wood, because the coordinate $a^{*}$ has an inverse correlation with the luminosity (see Table 4). The species itaúba (Mezilaurus itauba) was classified as olive brown due to a greater participation of the coordinate $\mathrm{a}^{*}$ and, consequently, lower luminosity.

The color coordinate $\mathrm{a}^{*}$ presented the best correlations with the basic density of the Amazonian tree species. In this research, we are observed which reddish woods presented higher basic density, with emphasis for the species A. leicontei, D. odorata e $H$. courbaril (see Table 3 and Figure 3). Similarly, Silva et al. (2019) found a positive correlation $(r=0.77)$ between color coordinate $\mathrm{a}^{*}$ and wood basic density of Calycophyllum spruceanum. According to Martins et al. (2015), the presence of certain chemicals in a greater or lesser amount in different parts of the trunk influenced the red shade of the wood. In woods with values of $a^{*}>10$, the red hue is more pronounced than the yellow ( $\left.b^{*}\right)$, with a predominance of red nuance in color formation (GONÇALEZ et al., 200 I; ATAYDE et al., 20I I; COSTA et al., 20I I). In this research we observed that values of $\mathrm{a}^{*}>7.4$ are associated with woods with a basic density higher than $0.83 \mathrm{~g} \cdot \mathrm{cm}^{-3}$.

Based on the regression model adjusted between the coordinate in the green-red axis ( $\left.\mathrm{a}^{*}\right)$ and the basic density, we observed that woods with $\mathrm{a} *-0.35$ have low basic density $\left(<0.50 \mathrm{~g} \mathrm{~cm}^{-3}\right)$. On the other hand, woods that presented the parameter a* between -0.35 and 4.64 were classified in the medium density group and the woods with the coordinate $\mathrm{a}^{*}>4.64$ are of high basic density $\left(>0.75 \mathrm{~g} \mathrm{~cm}^{-3}\right)$. Among the species studied only Hymenolobium modestum presented a* parameter ranging from 5.73 to 6.64 and basic density classified as 
moderate $\left(<0.75 \mathrm{~g} \cdot \mathrm{cm}^{-3}\right)$. This result can be attributed to the influence of extractives and parameter $b^{*}$ on the yellowish coloration of this wood (see Table 3 and Figure 3). The color coordinate blue-yellow (b*) present variations in the radial and tangential faces, which can be explained by the greater and lesser exposure of the radial parenchyma cells, respectively, which present accumulations of extractives in the lumen (GARCIA; MARINONIO, 2016).

The measurement of luminosity and red hue can assist technicians and researchers in the rapid and indirect assessment of the quality of Amazonian woods and, consequently, group them aiming at the most efficient processing and the most appropriate destination to different uses. The indices generated hereby include a wide colorimetric variation and can be used by other researchers and technicians of the forestry sector. The rapid determination of wood density, in addition to contributing to industry quality control, may help to replace overexploited species with other species with similar wood properties and sufficient forest growth stock (REIS et al., 2019).

The correlation analyses between the basic density and the color variables indicate that colorimetry can be used as a tool in the quality control of wood (SILVA et al., 2019), since the basic density is an important indicator of the strength, hardness, and durability of the wood (ARAÚJO, 2007). However, because of the large variability between species, a distinct or a species-specific pattern of correlations between the wood basic density and the colorimetric variables should be considered (GARCIA et al., 20I4) so that species-specif standards can be drawn.

\section{CONCLUDING REMARKS}

The evaluated tree species presented a difference of luminosity between the anatomical sections (tangential and radial). There was no statistically significant distinction between the chromatic variables $\mathrm{a}^{*}, \mathrm{~b}^{*}, \mathrm{C}^{*}$ and $\mathrm{h}^{*}$ in the different anatomical cutting planes. For commercial purposes, it is recommended to use luminosity in the classification of tangential and radial sawed parts according to market requirements.

The variability of wood color of Amazonian tree species influences the basic density and the industrial use of these materials. The correlation analyses between the wood basic density and luminosity $\left(\mathrm{L}^{*}\right)$ indicated that the denser woods are darker and have more reddish coloration ( $\left.\mathrm{a}^{*}\right)$. Overall, it was observed that woods with luminosity greater than 79 and coordinate $\mathrm{a}^{*}$ lower than -0.35 were classified as low density $\left(<0.50 \mathrm{~g} \cdot \mathrm{cm}^{-3}\right)$. On the other hand, woods with luminosity lower than 66 and with the coordinate a* greater than 4.64 was classified as high density. Thus, the parameters $L^{*}$ and $a^{*}$ can be used as quality indices for rapid classification, inferences about wood density and species separation into specific groups.

\section{ACKNOWLEDGMENTS}

This study was financed in part by the Coordenação de Aperfeiçoamento de Pessoal de Nível Superior - Brasil (CAPES), Finance Code 00I, and Conselho Nacional de Desenvolvimento Científico e Tecnológico (CNPq) in Brazil.

\section{REFERENCES}

ALMEIDA, T. H.; ALMEIDA, D. H.; ARAÚJO, V. A.; SILVA, S. A. M.; CHRISTOFORO, A. L.; LAHR, F. A. R. Density as estimator of dimensional stability quantities of Brazilian tropical woods. BioResources, v.12, n.3, p. 6579-6590, 2017.

AMORIM, P. G. R; GONÇALEZJ. C.; CAMARGOS, J. A. A. Wood properties of Eucalyptus grandis and Pinus caribaea estimated by colorimetry. Cerne, v. 19, n. 3, p. 46I-466, 2013.

ANDRADE, V. H. F; MACHADO, S. A. M.; FIGUEIREDO FILHO, A.; BOTOSSO, P. C.; MIRANDA, B. P.; SCHÖNGART, J. Growth models for two commercial tree species in upland forests of the Southern Brazilian Amazon. Forest Ecology and Management, v. 438, p. 215-223, 2019.

ARAÚJO, H. J. B. Relações funcionais entre propriedades físicas e mecânicas de madeiras tropicais brasileiras. Floresta, v. 37, n. 3, p. 399-416, 2007.

ASSOCIAÇÃO BRASILEIRA DE NORMAS TÉCNICAS - ABNT. NBR 7 190: Projeto de estruturas de madeira. Rio de Janeiro: ABNT. 1997. 107 p.

ATAYDE, C. M.; GONÇALEZ, J. C.; CAMARGOS, J. A. Características colorimétricas entre as seções anatômicas da madeira Muirapiranga (Brosimum sp.). Cerne, Lavras, v. I7, n. 2, p. 23।-235, 20। I.

AVILA, A. L.; SCHWARTZ, G.; RUSCHEL, A. R.; LOPES, J. C.; SILVA, J. N. M.; CARVALHO, J. O. P.; DORMANN, C. F; MAZZEI, L.; SOARES, M. H. M.; BAUHUS, J. Recruitment, growth and recovery of commercial tree species over 30 years following logging and thinning in a tropical rain forest. Forest Ecology and Management, v. 385, p.225-235, 2017.

BARRETO, C. C. K.; PASTORE, T. C. M. Resistência ao intemperismo artificial de quatro madeiras tropicais: o efeito dos extrativos. Ciência Florestal, v. 19, n. I, p. 2330, 2009.

BARROS, S. V. S.; MUNIZ, G. I. B.; MATOS, J. L. M. Caracterização colorimétrica das madeiras de três espécies florestais da Amazônia. Cerne, v. 20, n. 3, p. 337-342, 2014 
BATISTA, D. C.; KLITZKE, R. J.; ROCHA, M. P. Qualidade da secagem convencional conjunta da madeira de clones de três espécies de Eucalyptus sp. Ciência Florestal, v. 25, n. 3 , p. 7II-7I9, 2015.

BONFATTI JÚNIOR, E. A.; LENGOWSKI, E. C. Colorimetria aplicada à ciência e tecnologia da madeira. Pesquisa Florestal Brasileira, v. 38, e201601394, p. I-13, 2018.

BURGUER, L. M.; RICHTER, H. G. Anatomia da madeira. São Paulo, Nobel, Barueri, 1991. 154p.

CAMARGOS, J. A. A.; GONÇALEZ, J. A. A colorimetria aplicada como instrumento na elaboração de uma tabela de cores de madeira. Brasil Florestal, v. 20, n. 7I, p. 304 I, 200 I.

COSTA, J. A.; GONÇALEZ, J. C.; CAMARGOS, J. A. A.; GOMES, I. A. S. Fotodegradação de duas espécies de madeiras tropicais: jatobá (Hymenaea courbaril) e tauari (Couratari oblongifolia) submetidas à radiação ultravioleta. Cerne, v. 17, n. I, p. 133-139, 201 I.

COSTA, L. J.; LOPES, C. B. S; REIS, M. F. C.; CÂNDIDO, W. L.; FARIA, B. F. H.; PAULA, M. O. Caracterização anatômica e descrição físico-química e mecânica da madeira de Mimosa schomburgkii. Floresta, v. 47, n. 4, p. 383 -390, 2017.

CSANÁDY, E.; MAGOSS, E.; TOLVAJ, L. Quality of machined wood surfaces. Springer International Publishing: New York City, 20I5. 257 p.

DERKYI, N.S.A.; BAILLÈRES, H.; CHAIX, G.; THEVENOM, M.F.; OTENG-AMOAKO, A.A.; ADU-BREDU, S. Colour variation in teak (Tectona grandis) wood from plantations across the ecological zones of Ghana. Ghana Journal of Forestry, v. 25, p. 40-49, 2009.

EVANGELISTA, W. V.; COSTA, E. D. Avaliação de propriedades físico-anatômicas de duas madeiras usadas na produção de pisos. Revista de Ciências Agroambientais, v. I5, n.2, p. |33-|38, 2017.

FOREST PRODUCTS LABORATORY - FPL. Wood handbook: wood as an engineering material. Madison: U.S. Department of Agriculture, Forest Service, Forest Products Laboratory; 2010. 508p.

FORTINI, L. B. Integrated models show a transient opportunity for sustainable management by tropical forest dwellers. Forest Ecology and Management, v. 438, p. 233-242, 2019.

GARCIA, R. A.; OlIVEIRA, N. S.; NASCIMENTO, A. M.; SOUZA, N. D. Colorimetria de madeiras dos gêneros Eucalyptus e Corymbia e sua correlação com a densidade. Cerne, v. 20, n. 4, p. 509-5I7, 2014.

GARCIA, R. A.; MARINONIO, G. B. Variação da cor da madeira de teca em função da densidade e do teor de extrativos. Floresta e Ambiente, v. 23, n. I, p. I24- I34, 2016.
GONÇALEZ, J. C.; JANIN, G.; SANTORO, A. E.; COSTA, A. A.; VALE, A. Colorimetria quantitativa: uma técnica objetiva de determinar a cor da madeira. Brasil Florestal, n. 72, p. 47-58, 200I.

GRIEBELER, C.; TONDI, G.; SCHNABEL, T.; IGLESIAS, C.; RUIZ, S. Reduction of the surface colour variability of thermally modified Eucalyptus globulus wood by colour pregrading and homogeneity thermal treatment. European Journal of Wood and Wood Products, v.76, n. 5, p. |495-1504, 2018.

HITTLER, C. R.; FREESE, F.; SMITH, D. M. Relationships in black walnut heardwood between color and other physical and anatomical characteristics. Wood and Fiber Science, v. 4 , n. I, p. 38-42, 1972.

INSTITUTO DE PESQUISAS TECNOLÓGICAS - IPT. Catálogo de madeiras brasileiras para a construção civil. Coordenação Augusto Rabelo Nahuz. São Paulo: IPT - Instituto de Pesquisas Tecnológicas do Estado São Paulo, 2013. 103 p.

KONICA MINOLTA. Precise color communication: Color control from perception to instrumentation. Konica Minolta Sensing Inc., Japan, 2007. 59 p.

LAHR, F. A. R.; CHRISTOFORO, A. L.; SILVA, C. E. G.; ANDRADE JUNIOR, J. R.; PINHEIRO, R. V. Evaluation of physical and mechanical properties of jatobá (Hymenaea stilbocarpa Hayne) wood with different levels of moisture content and different regions of extracions. Revista Árvore, v.40, n. I, p. I47-154, 2016.

LOCOSSELLI, G.M.; KROTTENTHALER, S.; PITSCH, P.; ANHUF, D.; CECCANTINI, G. Age and growth rate of congeneric tree species (Hymenaea spp. - Leguminosae) inhabiting different tropical biomes. Erdkunde, v. 7I, n. I, p. $45-57,2017$

LUOSTARINEN, K.; MÖTTÖNEN, V. Effect of felling season, storage and drying on colour of silver birch (Betula pendula) wood from different growing sites. Silva Fennica, v. 43, n. 4, p. 699-709, 2009.

MAIA, J.H.; MOURA, M.G.D.; MAGALHÃES, A.S.; CASTRO, V.G. Comportamento colorimétrico da madeira de maçaranduba tratada com produtos de acabamento. Nativa, v. 6, n. especial, p. 767-772, 2018.

MARTINS, M. F; BELTRAME, R.; DELUCIS, R. A.; GATTO, D. A.; CADEMARTORI, P. H. G; SANTOS, G. A. Colorimetria como ferramenta de agrupamento de madeira de clones de eucalipto. Pesquisa Florestal Brasileira, v. 35, n. 84, p. 443-449, 2015.

MELO, L. E. L.; SILVA, J. R. M.; NAPOLI, A.; LIMA, J. T.; TRUGILHO, P. F.; NASCIMENTO, D. F. R. Study of the physical properties of Corymbia citriodora wood for the prediction of specific cutting force. Scientia Forestalis, v. 44 , n. III, p.70I-708, 2016 
MELO, R. R.; STANGERLIN, D. M.; DEL MENEZZI, C. H. S.; CASTRO, V. G.; SOUZA, M. J. C.; MEDEIROS, D. T. Grouping of commercial tropical timber using wood color. Revista de Ciências Agrárias, v. 62, p. I-6, 2019.

MESQUITA, R. R. S.; GONÇALEZ, J. C.; PAULA, M. H. Comportamento da madeira de Tectona grandis frente ao intemperismo. Floresta, v. 47, n. I, p. 29 - 35, 2017.

MÖTTÖNEN, V.; KÄRKI, T. Effect of drying force on birch wood colour change during high temperature drying. Baltic Forestry, v. I3, n. I, p. I26-130, 2007.

MOYA, R.; BERROCAL, A.; Wood colour variation in sapwood and heartwood of young trees of Tectona grandis and its relationship with plantation characteristics, site, and decay resistance. Annals of Forest Science, v. 67, n. I, p. 109-109, 2010.

MOYA, R.; MARIN, J.D. Grouping of Tectona grandis (L.f.) clones using wood color and stiffness. New Forests, v. 42, n. 3, p. 329-345, 201 I.

NISHINO, Y.; JANIN, G.; YAINADA, Y.; KITANO, D. Relations between the colorimetric values and densities of sapwood. Journal of Wood Science, v. 46, n. 4, p. 267-272, 2000.

NOGUEIRA, E. M.; NELSON, B. W.; FERNSIDE, P. M. Wood density in dense forest in central Amazonia, Brazil. Forest Ecology and Management, v. 208, n. I-3, p. 26I-286, 2005.

OLIVEIRA, E. M.; BRAGA, J. W. B.; COSTA, A. F. Discriminação de madeiras similares por fluorescência molecular e mínimos quadrados parciais. Química Nova, v. 38, n. 9, II76-I I80, 2015.

PEREIRA, A. F. Madeiras Brasileiras: Guia de combinação e substituição. FAPEMIG. I. ed. São Paulo: Editora Blucher, 2013. 130p.

PINCELLI, A. L. P. S. M.; MOURA, L. M; BRITO, J. O. Effect of thermal rectification on colors of Eucalyptus Saligna and Pinus Caribaea woods. Maderas. Ciencia y Tecnología, v. I4, n.2, p.239-248, 2012.

R CORE TEAM. R: A language and environment for statistical computing. https://www.R-project.org/, 2017 (accessed I3 August 2019).

REIS, P. C. M. R.; SOUZA, A; L.; REIS, L. P.; CARVALHO, A M. M. L.; MAZZEI, L.; REIS, A. R. S.; TORRES, C. M. M. E. Agrupamento de espécies madeireiras da Amazônia com base em propriedades físicas e mecânicas. Ciência Florestal, v. 29, n. I, p. 336-346, 2019.

SANDOVAL-TORRES, S.; JOMAA, W.; MARC, F;; PUIGGALI, J.-R. Causes of color changes in wood during drying. Forest Studies in China, v. I2, n. 4, p. 167-175, 2010.
SCOTT, A. J.; KNOTT, M. A cluster analysis method for grouping means in the analysis of variance. Biometrics, v. 30 , n. 3, p. 507-5I2, 1974.

SETTE JUNIOR, C. R.; OLIVEIRA, I. R.; TOMAZELLO FILHO, M.; YAMAJI, F. M.; LACLAU, J. P. Efeito da idade e posição de amostragem na densidade e características anatômicas da madeira de Eucalyptus grandis. Revista Árvore, v.36, n.6, p.II83-II90, 2012.

SILVA, E. S.; STANGERLIN, D. M.; GATTO, D. A.; CALEGARI, L.; PARIZ, E. Colorimetria da madeira de oito espécies nativas do estado do Rio Grande do Sul, Brasil. Ciência da Madeira, v. 6, n. I, p. 3I-37, 2015.

SILVA, R. A. F.; SETTER, C.; MAZETTE, S. S.; MELO, R. R.; STANGERLIN, D. M. Colorimetria da madeira de trinta espécies tropicais. Ciência da Madeira, v. 8, n. I, p. 36$41,2017$.

SILVA, S. B.; ANDRADE, J. K. B; ARANTES, M. D. C.; SILVA, J. G. M.; BROCCO, V. F.; PAES, J. B. Color variability and relationship with basic density and extractive content of Calycophyllum spruceanum wood. Floresta, v. 49, n. 4, p. $803-812,2019$.

STANGERLIN, D. M.; CAVALCANTE, C. F. P.; COSTA, C. A.; PARIZ, E.; MELO, R. R.; DALL'OGLIO, O. T. Propriedades mecânicas de madeiras amazônicas estimadas por meio de métodos de propagação de ondas ultrassonoras. Nativa, v.5, esp., p. 628-633, 2017.

STANGERLIN, D. M.; COSTA, A. F;; GONÇALEZ, J. C.; PASTORE, T. C. M.; GARLET, A. Monitoramento da biodeterioração da madeira de três espécies amazônicas pela técnica da colorimetria Acta Amazonica, v. 43, n. 4, p. 429-438, 2013.

TELES, R. F;; COSTA, A. F. Influência do intemperismo acelerado nas propriedades colorimétricas da madeira de Angelim pedra. Nativa, v. 02, n. 02, p. 65-70, 2014.

VIEIRA, H. C.; SILVA, E. L.; SANTOS, J. X.; MUÑIZ, G. I. B.; MORRONE, S. R.; NISGOSKI, S. Wood colorimetry of native species of Myrtaceae from a araucaria forest. Floresta, v. 49, n. 2, p. 353-362, 2019.

YAZAKI, Y.; COLLINS, P. J., MCCOMBE, B. Variations in hot water extractives content and density of commercial wood venners from blackbutt (Eucalyptus pilularis). Holzforschung, v. 48, suppl., p. I07-I I I, 1994.

ZANUNCIO, A. J. V; FARIAS, E. S; SILVEIRA, T. S. Termorretificação e colorimetria da madeira de Eucalyptus grandis. Floresta e Ambiente, v. 21, n. I, p. 85-90, 2014. 